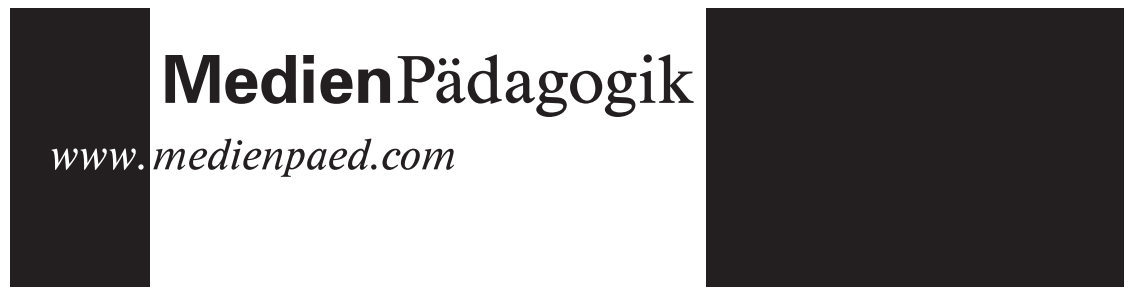

\title{
The Status of Internet Education in Japanese and German Guidelines on ICT and Media Education
}

\begin{abstract}
This paper tries to locate references to Internet related elements in curricula and guidelines for general education in Japan and Germany from around 1985 to the present. The most obvious difference is the historically grown concentration on «information» in Japan vs. «media» in Germany (although in Germany informatics exists as a general school subject) and accordingly the assignment of Internet related content to the respective area. The guidelines do not differ much in that they stress comparable general aims of education, but differences in focus become visible through examination of the detailed content listed for information and media education. The paper concludes with suggestions to further pursue some of the strong points from both approaches.
\end{abstract}

\section{Contents}

1 Introduction $\quad 2$

1.1 Context and Aim . . . . . . . . . . . . . . . . . . . 2

1.2 Material and Terminology . . . . . . . . . . . . . . 3

1.3 Educational Systems and Internet Introduction into Schools in Japan and Germany ......................... 4

2 Information Literacy and the Internet in Japanese Educational Guidelines 6

2.1 Information, Technology and Media Education before 1994 . . . . . . . . . 6

2.1.1 Media education ................. 6

2.1.2 Technology education ............... 6

2.1.3 Information education . . . . . . . . . . . 6

2.2 Recent Vision Documents, Guidelines and Curricula . . . . . . . . . . . 8

2.2.1 The Central Council for Education's 1st Report on Japan in the 21st Century (1996.07) . . . . . . . . . . . . . . 8

2.2.2 The Report of the Information Education Research Council (1997.10) 10

2.2.3 The Curriculum Council's Report (1998.07) . . . . . . . . . . . . . 11

2.2.4 Curriculum for the High School Subject «Information» (1999.03) . 12

2.3 Summary of Key Concepts in Japan . . . . . . . . . . . . . . . . . . 13

3 Media Competence and the Internet in German Educational Guidelines 14

3.1 Information Technology and Media Education before 1995 . . . . . . . . . 14

3.1 .1 Media Education . . . . . . . . . . . . . . . . . 14

3.1.2 Basic Information Technology Education . . . . . . . . . . 15 
3.1.3 The Subject Informatics . . . . . . . . . . . . . . . . 16

3.2 Recent Guidelines and Suggestions . . . . . . . . . . . . . . . . 16

3.2.1 BLK's Orientation Framework for Media Education (1995) . . . . . 17

3.2.2 KMK's Declarations from 1995 and $1997 \ldots \ldots$. . . . . . . . . 18

3.2 .3 Bavaria ....................... 19

3.2 .4 Hesse . . . . . . . . . . . . . . . . 20

3.2.5 North Rhine-Westphalia (NRW) . . . . . . . . . . . . . . 20

3.2 .6 Thuringia ...................... 21

3.3 Summary of Key Concepts in Germany . . . . . . . . . . . . . . . . 23

4 Comparison and Suggestions $\quad 24$

4.1 Common Tasks, Different Foci . . . . . . . . . . . . . . . . . . 24

4.2 Suggestions for Integration . . . . . . . . . . . . . . . 25

References $\quad 26$

$\begin{array}{ll}\text { URLS } & \mathbf{3 0}\end{array}$

\section{Introduction}

\subsection{Context and Aim}

The Internet can enable the individual with respect to intellectual and communicative endeavours in an unprecedented way. It opens up access to the most diverse sources of information and communication partners from all over the world. Together with high-capacity personal computers an individual nowadays can conduct operations and create products that used to be reserved to organisations like computer centres, companies like publishing houses plus distributors, middle scale libraries, musician plus sound engineer plus record company plus distributor etc. Education that aims at enabling students and fostering a self-determined attitude towards life, should have an interest to explore this area and make its possibilities available to every student. On the other hand, information technology in the hands of interested parties poses unprecedented threats to privacy and «informational self-determination» ${ }^{1}$. Individuals have to know the implications of information related actions in our «informatised» society. Further, the sheer masses and diversity of available information and options for action (way beyond the consumption oriented options given by traditional broadcasting media) can pose a considerable challenge to orientation. It is not clear, how phenomena of «digital divide» can be prevented. So chances for self-determined information related activities, for (lifelong) learning in a constructivistic sense are high, and the tasks of coping with change and overwhelming possibilities are huge.

Accordingly general education is challenged to provide orientation free of commercial interests, by well-prepared teachers and in accordance with general pedagogic aims such as physical and mental robustness of the students, orientation towards freedom, self-determination, participation and solidarity.

The aim of this paper is to compare two approaches by two industrialised countries with comparable economic weight, but from different cultural backgrounds to a similar problem of global importance: How are elements of Internet literacy being implemented into concepts of general education? In particular, where do we find reference to Internet related education in curricula and frameworks that are in force right now - eight years after

${ }^{1}$ German: «informationelle Selbstbestimmung» 
the World Wide Web became more «visible» to general users through graphic interfaces? What is the conceptual framework the Internet is being dealt with? And even if the Internet does not play a prominent role, what is the main focus of the literacy concepts involved? The paper is meant as an introduction to primary material in Japanese and German for an English reading research community. My hope is that knowing different approaches might help to see points of emphasis, strengths and weaknesses more clearly than when concentrating on a single culture, and that new insights might result in improvement of Internet education.

\subsection{Material and Terminology}

The material I use for content analysis mainly consists of official curricula and educational guidelines that are in force or have been already accepted at the time of writing (July 2001). For the sub-chapters on history I use documents from about the middle of the $1980 \mathrm{~s}$ up to 1994-95. Around 1985 in both countries basic computer related education started to be discussed, and around 1995 the Internet had gained enough popularity to be discovered by educational policy. In order to make a selection from the vast material available, I particularly chose publications that deal with media literacy, information literacy or informatics/computer science content, because there I expect the most systematic and up to date approaches to the topic. This also means that I do not make statements about Internet related content in the many different subjects. As for documents from German states the online availability was an additional criterion. From each of the more recent documents I extract and translate the main aims of information respectively media education and statements about the role of the Internet (if any).

Terminology is a major problem. First of all I attempt to translate value loaded terms with deep roots in the respective educational culture into English. The result often remains debatable $^{2}$. If in doubt, I try to keep the translations rather literal in order to preserve more of the original flavour. For central concepts I also add the original wording. The second problem is an intra-language one: Difficult to grasp educational key concepts in particular are very much subject to debate, and their meaning not only changes trough time, but also according to different authors. When presenting different documents I therefore try to preserve enough of the context for the reader to be able to construct the particular meaning within its context.

Although I try to let the original documents speak for themselves, I should also add a short explanation of my own terminological basis and ideological context as a background for translation and interpretation:

By «Kulturtechnik» I mean skills that enable the individual, enhance his/her freedom, dependent on the socio-cultural as well as the individual needs context. Traditionally, especially reading, writing and calculating were Kulturtechniken conveyed through school education. The acquisition of Kulturtechniken should not be a passive process, but an active construction. This self-enabling ability is one aspect of «Mündigkeit» («majority»), (in the Kantian tradition) the ability to use one's reason independently and act responsibly. With «literacy» («Grundbildung») I refer to the individual command over Kulturtechniken, i.e. the ability to participate in social infrastructure on the basis of socially relevant, individualised knowledge and skills. In this article, I use «literacy» and «competence» (as in «media literacy» or «media competence») as synonyms. I use «education» in the sense of the German «Bildung». One aim of «general education» («Allgemein-Bildung») is to help

\footnotetext{
${ }^{2}$ see e.g. the much less critical translation of the German «Informationstechnik» into «information technology». In general, German, similar to English, distinguishes «Technik» («technique», technical artefacts) as the rather physically based aspect of artefacts or procedures from «Technology» («technology»), which includes more of the intellectual and social context. Nevertheless, in some cases the German «Technik» also is used in a broader sense and thus can be better translated as «technology».
} 
the individual to acquire the Kulturtechniken of his/her time that are most likely to be of individual use.

PCs, personal media (broadcasting media only to a small extent) and Internet access have come into reach of the individual and have become an important means for enabling people to an active acquisition of the world (in wealthy countries at the end of the 20th, beginning of the 21st century). Thus a new set of «Kulturtechniken» has become necessary. Especially the diffusion of the Internet has added new momentum to discussions of key educational content and it can help as a focal point for re-assessing traditional informatics/computer science education as well as media education. Because computers and networks are both, tools for information processing and media, Internet literacy includes aspects of «information literacy» as well as «media literacy» («media» here in the sense of technical media).

«Information literacy» and «media literacy» have overlapping areas, e.g. in the field which deals with the content of information respectively media messages. Differences in stress can be seen in the fact that «media literacy» (with aspects like selection, critical assessment etc.) historically has a strong connection to broadcast media. «Information literacy» includes information processing aspects like in a recent broad definition of «informatics literacy» («informatische Bildung») as «the result of learning processes in which foundations, methods, applications, modes of operation and social significance of information and communication technologies are to be explored» [Hauf-Tulodziecki 1999, 121]. A modern integration of the two concepts with respect to information and communication technology (within frameworks of the information or knowledge society) would be desirable, with the aspect of enabling the individual at the centre.

\subsection{Educational Systems and Internet Introduction into Schools in Japan and Germany}

The year 1994/95 can be seen as a borderline for Internet introduction into schools in Japan and Germany. In 1994 the first national model project was proposed in Japan ("100 Schools Project"3). 1995 in Germany plans for a similar project («Schulen ans Netz», $\mathrm{SaN}^{4}$ ) were created $^{5}$. Since these years at least in certain circles of educational policy the Internet had been recognised as a factor. Unfortunately, these projects started with equipping schools with hard- and software, but the development of concepts for a meaningful use of the technology as well as teacher training lagged far behind. Although concepts like «lifelong learning» are being proposed all over the place, the school system itself still has not been able to produce a satisfying solution.

The organisational basis for educational policy in general differs in both countries:

In Germany in principle the 16 federal states («Länder») own sovereignty with respect to cultural affairs including education. On the federal level two main central bodies work on coordination between the states in order to guarantee certain standards and facilitate mobility: In the BLK (Bund-Länder-Commission for Educational Planning and Research Promotion $)^{6}$ all education and research related issues of concern to both the federal government and the states are being discussed. In the KMK (Standing Conference of the Ministers of Education and Cultural Affairs of the Länder) ${ }^{7}$ all Ministers of Education, Science, Culture and Sports from the states work together for compatibility of Länder policies. In recent years the federal Ministry of Education and Research (BMBF) also tries to push the technological development by supporting school networking projects like SaN, but legally it has no means to force a state government to introduce certain types of education. Thus, in

\footnotetext{
${ }^{3}$ http: //www.cec.or.jp/e-cec/CEC \_100school.html ("100 Schools Project")

${ }^{4}$ http: //www.san-ev.de (SaN)

${ }^{5}$ for a detailed history of projects cf. [Langner 2000]

${ }^{6}$ Bund-Länder-Kommission für Bildungsplanung und Forschungsförderung

${ }^{7}$ Ständige Konferenz der Kultusminister der Länder in der Bundesrepublik Deutschland (KMK)
} 
developing areas like Internet use we find considerable differences between the states.

As for the school system, most schools are public schools. Elementary school in most states is 4 years, and parents can chose different school types (from practically to academically oriented, 5-9 years) from grade 5 onwards.

Japan's educational system is centralistly organised with all responsibility residing with the Ministry of Education (Monbushou ${ }^{8}$ ). The binding national Course of Study for primary and secondary education ${ }^{9}$ appears every 10 years. Various councils, especially the Central Council for Education ${ }^{10}$ (CCE) and the Curriculum Council ${ }^{11}$ (CC), work out recommendations for improving the Course of Study and for other measures of educational policy.

General education in Japan is organised in comprehensive schools, with elementary school grades 1-6, middle school grades 7-9, and high school grades 10-12. Numerous private schools compete for students, so differentiation occurs not between school types, but between concrete schools.

As for approaches of locating Internet use at school within educational guidelines we find interesting differences between the two countries:

In Germany most recent documents on the federal level try to incorporate the Internet into concepts of «media education». The traditionally strong emphasis on a critical attitude towards and emancipation from media is also applied to the Internet, and instrumental and information related aspects play a secondary role. Media education is put into the general pedagogic context which aims at educating individuals who act «adequately, in a self-determined way, creatively and socially responsibly». State curricula for media education in lower secondary grades (5-10) mostly follow the BLK approach [BundLänder-Kommission für Bildungsplanung und Forschungsförderung (BLK) 1995] closely. In guidelines for higher secondary education (grades 11-13) however, the most thorough examination of the topic seems to take place within the framework of the subject «informatics».

In Japan, on the other hand, the Internet is mostly treated within the context of «information literacy» discussions. «Response to the information society» is frequently mentioned as one important element of educational reform (cf. e.g. Monbushou's «Program for Educational Reform» from 1997 [Monbushou 1997]): Since around the middle of the 1980s the need was felt to «set up a more creative and vital Japanese society in the 21 st century» [Tsukuba Kokusai Kyouiku Kenkyuukai 1998, 56]. In the 1989 Course of Study a «new view on school achievements» («shin gakuryoku kan») was proposed: Whereas so far «knowledge» («chishiki») and «understanding» («rikai») had been the key concepts, now the order was reversed, and process and development oriented values like «interest» («kanshin»), «will» («iyoku») and «attitude» («taido») of the students were given primary importance. The concept of «living strength» («ikiru chikara») received a prominent status among the educational goals (cf. [IMAI Yasuo 1998, 185]). In recent years these concepts are frequently related to the concept of the information society and its implications for education.

\footnotetext{
${ }^{8}$ Today: «Monbu-Kagaku-Sho», but I use the old and more familiar name here.

${ }^{9}$ «Gakushuu Shidou Youryou», literally: «Guidelines for Learning and Teaching»

$10 \ll$ Chuuou Kyouiku Shingikai»

11 «Kyouiku Katei Shingikai»
} 


\section{Information Literacy and the Internet in Japanese Educational Guidelines}

\subsection{Information, Technology and Media Education before 1994}

\subsubsection{Media education}

Analog media have a long history of educational use in Japan. Educational radio broadcast started in 1935, educational television in 1959, and video technology became popular in the 1960s and 1970s [Muranoi H.; Mishima H.; Inui S.; Ohnogi H. 1999, 29-31]. Traditional media education is usually summarised under the term «audio-visual education» («shichoukaku kyouiku»), a topic dealt with in different subjects where appropriate.

As for the term «media», even after computers and «multimedia» had entered the scene, my impression is that it has generally not played a role as important as in German educational policy. If we look at CCE reports from the early 1990s, already at that time «informatisation» is mentioned as an important trend, whereas a similar reference to «media» is lacking. Although around 1994 we also find «educational media» («kyouiku media») as a generic term including analog media as well as computers, multimedia and networks (e.g. [MIZUKOSHI Toshiyuki; AKAHORI Kanji 1995]), the tendency to cover (multi)media within the area of «informatisation» seems to be stronger. In one of the main annual Monbushou publications, «Japan's Educational Policy», of 1994 we find 2 pages on (mainly «audio-visional») «educational media», but a chapter of 14 pages on «informatisation» [Monbushou 1994]. In the 1998 edition this chapter has grown to 22 pages, including several references to «multimedia». Only one page remains for «audiovisual education» [Monbushou 1998].

\subsubsection{Technology education}

Since 1962 general middle schools have a compulsory subject «technology and home economics» («gijutsu-katei»), which deals with the foundations of life in our modern society on different levels and tries to foster a practical attitude towards leading one's life. The 1989 course of study (which for the first time contains a unit «information basics») explains the aim of the subject as follows: «To deepen understanding about the relation between the livelihood («seikatsu») of households rsp. society and technology («gijutsu») through acquisition of basic knowledge («chishiki») and skills («gijutsu») that are necessary for everyday life. Further to foster the ability to plan and create as well as a practical attitude» $^{12}$.

The following topics are listed under this subject: A) Woodwork, B) Electricity, C) Metal Work, D) Machines, E) Planting, F) Information Basics (content see 2.1.3), G) Household Life, H) Food, I) Clothing, J) Housing, K) Nursing [Monbushou 1989].

10 years later the subject content is divided into two parts. Under «technology» we find the topics A) «Technology and Construction of Things» (including industry, product design, tools and machines, their construction and maintenance, transformation of energy, planting of crops), and B) Information and Computers. The «home economics» part covers A) «Independent life and necessities of life (clothing, food, housing)» and B) «Family and life of the household» [Monbushou 1999a].

\subsubsection{Information education}

In the middle of the 1980s educational policy discovered «informatisation» («jouhouka») as an issue that called for policy response, together with other elements of social change,

\footnotetext{
12 «seikatsu» can be translated as «everyday life» or «livelihood», «gijutsu» can be translated as «technology», «technique», «art» or «skill».
} 
like «internationalisation», «industrial restructuring», the «trend towards nuclear families», and the «aging society» (cf. e.g. the Council for Education's report from November 1983, mentioned by [YAMAGIWA Takashi 1991, 6]).

According to Mizukoshi [MizUKOSHI Toshiyuki 1990, 50] the concept of «ability to use information» («jouhou katsuyou nouryoku») had been taken into the public discussion by the 1986.04 report of the Prime Minister's Ad Hoc Council on Education. This report defines «ability to use information» as «the basic gift of an individual to actively select and use information as well as information means» ${ }^{13}$ and puts it on a par with the basics of reading, writing and calculating [Jouhouka no shinten ni taiou shita shotou chuutou kyouiku ni okeru jouhou kyouiku no suishin nado ni kansuru chousa kenkyuu kyouryokusha kaigi 1997].

In August 1985 a research council with the task to make proposals how to adopt to informatisation in primary and secondary education ${ }^{14}$ had delivered its first report to the Ministry of Education. It had identified the following aspects of «ability to use information»:

- «the ability to judge, select, organise and process information and the ability to create and communicate new information» 15

- «understanding of the characteristics of the information society and of the influence of informatisation on society and people» 16

- «recognition of the importance of information, the feeling of responsibility for information» ${ }^{17}$

- «understanding the basics of informatics and characteristics of information means (especially computers), acquirement of basic handling abilities» ${ }^{18}$. (cf. [MIZUKOSHI Toshiyuki 1990, 50f] and [YAMAGIWA Takashi 1991, 8]).

The ministry took up the suggestions and came up with the following elements in its report from April 1986:

- «the ability to decide with one's own critical mind to select what one seeks from various and diverse information ${ }^{19}$

- the ability to skilfully use information and information means in the process of accomplishing one's goals ${ }^{20}$

- the ability to produce information by oneself and to transmit them via information means ${ }^{21}$

- a moral perspective towards the use of information and information means ${ }^{22} \gg($ see [YAMAGIWA Takashi 1991, 7]).

So in this definition we find the aspects self-determination, selection of information, skilful use of information and related means, information creation, communication of information, and responsible use of information and information means.

\footnotetext{
13 «Jouhou oyobi jouhou shudan o shutaiteki ni sentaku shi, katsuyou shiteiku tame no kojin no kisoteki na shishitsu».

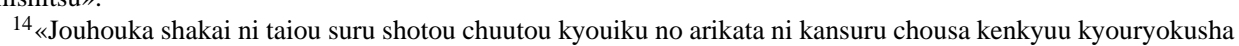
kaigi»

${ }^{15}$ «jouhou no handan, sentaku, seiri, shori nouryoku oyobi arata na jouhou no souzou dentatsu nouryoku»

16 «jouhouka shakai no tokushitsu, jouhouka no shakai ya ningen ni taisuru eikyou no rikai»

17 «jouhou no juuyousei no ninshiki, jouhou ni taisuru sekininkan»

18 «jouhou kagaku no kiso oyobi jouhou shudan (toku ni konpyuuta) no tokuchou no rikai, kihonteki na sousa nouryoku no shuutoku»

19 «jibun no mondai ishiki o kakutei shite tashu tayou na jouhou no naka kara, jibun no motomeru mono o sentaku suru nouryoku»

${ }^{20}$ «jouhou oyobi jouhou shudan o jibun no mokuteki no suikou no katei no naka ni jouzu ni katsuyou shiteiku nouryoku»

${ }^{21}$ «jibun de jouhou o seisan shi, jouhou shudan o tooshite sore o hasshin shiteiku nouryoku»

22 «jouhou oyobi jouhou shudan no riyou ni kansuru rinrikan»
} 
In the following, various councils took up this definition, and to a certain extent it also entered the new Course of Study from 1989. In particular for the first time an (optional) unit «information basics» («jouhou kiso») was added to the middle school subject «technology and home economics» [KAMEYAMA Hiroshi 1994]. Its aim was "to make [students] understand about the role and functions of computers through handling them and to promote the basic ability to use information in an appropriate way". It consisted of the following topics:

1. Computer construction: a) basic construction and functions of parts (e.g. input, operation, control, memory, output); i) software functions

2. Basic computer handling and easy programming: a) basic handling; i) knowing functions of a program, ability to write easy programmes

3. Computer use: a) use information with the help of software (e.g. Japanese word processing, database, spreadsheet, drawing software, selection, arranging, processing, expression of information); i) knowing application areas of computers

4. Role and influence of information and computers on daily life and industry [Monbushou 1989].

We find that the actual implementation of a relatively broad concept in theory remained limited to understanding and handling computer hard and software aspects as well as some insights into social structures.

Mizukoshi reports about the limitations as follows: First of all, information literacy education tended to remain restricted to computer use. Although the recommendations for primary school had included «getting in contact with and getting used to computers», the guidelines did not clarify how this was to happen in the context of existing subjects. The guidelines for middle school restricted computer use to the sciences and did not talk about applications in languages, social sciences etc. Although «information basics» was introduced into the subject technology, it only received the status of one of eleven units from which seven or more had to be chosen. In the high school guidelines elements of computer use could be found in several subjects, but overall there was a bias towards programming and handling aspects, and the area of information and society did not receive enough attention [MizuKOSHI Toshiyuki 1990, 51f] ${ }^{23}$.

Despite of the strong emphasis given to the phenomenon of informatisation and although in professional education the subjects "information technology" and "information processing" had already been introduced in 1970, no such subject entered Japanese general education in the later 20th century.

\subsection{Recent Vision Documents, Guidelines and Curricula}

\subsubsection{The Central Council for Education's 1st Report on Japan in the 21st Century (1996.07)}

This report [Chuuou Kyouiku Shingikai 1996] describes a vision how education in Japan should look like in the 21 st century and consists of the three parts: «Future education», «Roles of and interrelations between school, family and the local society», and «Education in response to social changes like internationalisation, informatisation and progressing science and technology» ${ }^{24}$.

\footnotetext{
${ }^{23} \mathrm{cf}$. the accounts of [Jouhouka no shinten ni taiou shita shotou chuutou kyouiku ni okeru jouhou kyouiku no suishin nado ni kansuru chousa kenkyuu kyouryokusha kaigi 1997, Chapter 1.2] which state that the situation had not improved very much by 1997.

${ }^{24}$ The followup report from 1997 [Chuuou Kyouiku Shingikai 1997b] deals with different topics, but for this report an official English version is available [Chuuou Kyouiku Shingikai 1997a], so it can serve as a source for translations of common key phrases.
} 
The document has as its motto «living strength and space for the children» ${ }^{25}$. This notion of «living strength» or «zest for living» is explained as follows: «'Zest for living' is the ability to identify problems for oneself, learn for oneself, think for oneself, make independent judgements and actions and solve problems well». It also includes cultivating «a rich sense of humanity» [Chuuou Kyouiku Shingikai 1997a, I.(1)] ${ }^{26}$.

Here especially chapter 3.3 on informatisation and education ${ }^{27}$ is of interest. It consists of five points: «Informatisation and education», «Systematic implementation of information education», «Qualitative improvement of school education through the use of information devices and information networks», «The construction of a «new school» that responds to the high degree information and communication society», and «Response to the dark sides of informatisation». The «high degree information and communication society» ${ }^{28}$ that meanwhile has become a reality, is characterised through diffusion of Internet, multimedia, PCs and mobile phones and masses of people from all over the world being able to exchange information like text, sounds and images via international networks. School has to acknowledge that children of today can access information that exceeds the information transported via school education in amount, diversity and also attractivity (3.3.1).

The report states that the aim of information education is to foster «the basic gifts and abilities» ${ }^{29}$ that constitute information literacy for the high degree information and communication society, such as the ability to actively chose information and information devices, use them and send out information. Students shall be enabled to understand, chose, arrange, create and transmit information. They shall know the possibilities and limits of using information devices. The overall aim is to educate humans with mind and body in harmony, so it is also important to watch the risks of information technology for primary experience, health and social life (3.3.1).

Already in this report we find the call for «systematic information education» throughout all school grades. The main emphasis is on using computers and networks skilfully as tools. It is recommended that in elementary school students mainly should get used to computers. In middle school adequate use of information, including computer use, plays an important role. The «period for integrated study» is recommended for learning activities with networks. In the different subjects the computer can be used to enrich educational content, e.g. help with topic finding, information collection, processing and presentation of survey results etc. In high school computer use should be intensified in the various subjects (3.3.2).

As for the role of the Internet, the use of global «information and communication networks» is taken for granted as a basic skill in the information society along with the use of other information devices throughout the document. Sub-chapter 3.3.3 is almost entirely devoted to information networks, represented by the Internet. The authors call for a serious standardised («honkakuteki») use of the Internet in schools. Especially possibilities like access to various institutions and information sources as well as collaboration, i.e. opening up of schools, broadening of perspectives and real encounters, are stressed (3.3.3).

\footnotetext{
25 «kodomo ni 'ikiru chikara' to ‘yutori' o». In [Chuuou Kyouiku Shingikai 1997a] this phrase is translated as «cultivating 'zest for living' amid 'room to grow' in children».

${ }^{26}$ cf. [Chuuou Kyouiku Shingikai 1996, I.(3)]«jibun de kadai o mitsukete, mizukara manabi, mizukara kangae, shutaiteki ni handan shi, koudou shi, yori yoku mondai o kaiketsu suru shishitsu ya nouryoku de ari, mata mizukara o risshi tsutsu, tanin to tomo ni kyouchou shi, tanin o omoiyaru kokoro ya kandou suru kokoro nado, yutaka na ningensei de aru». The second part which elaborates on the different elements of «a rich sense of humanity» have no direct counterpart in the English version, but can also be found at other places of the document, e.g. as «consideration for others», «harmony of society» etc.

${ }^{27}$ http: //www.mext.go.jp/b_menu/shingi/chuuou/toushin/9607010.htm (chapter 3.3 on informatisation and education)

28 «koudo jouhou tsuushin shakai»

29 «kisoteki na shishitsu ya nouryoku»
} 


\subsubsection{The Report of the Information Education Research Council (1997.10)}

In October 1996 a research council on information education in primary and secondary schools ${ }^{30}$ was set up in order to research the situation in more detail and to develop concrete suggestions. In October 1997 it delivered its report [Jouhouka no shinten ni taiou shita shotou chuutou kyouiku ni okeru jouhou kyouiku no suishin nado ni kansuru chousa kenkyuu kyouryokusha kaigi 1997] in which the term «jouhou katsuyou nouryoku» («ability to use information» - here explicitly equated with the English term «information literacy» ) is the key concept.

The aims of information education are defined by the report (chapter 2.1) as follows:

- «(1) ability to actively collect, judge, express, process, create nessecary information - this includes the use of information means appropriate for a certain topic and aim -, stepping on a receiver's situation also the ability to send out and transmit information (in the following called 'practical ability to use information, ${ }^{, 31}$ )

- (2) understanding of the characteristics of information means, which form the basics of information use, and understanding of basic theory and methods to appropriately handle information and to evaluate and improve one's own information use (in the following called 'scientific understanding of information, 32 )

- (3) An attitude to understand the role of information and information technology for our social life and their influence on it, to think about the necessity of information moral and responsibility for information and to participate in the creation of a desirable information society (in the following called 'attitude to actively participate in the information society' ${ }^{33}$ ).

- Further, in real learning situations there is a need to experience the concrete use of information means and to learn at least their basic handling. (By information means here we mean information devices like computers, information networks etc.).»

An important aspect is the relationship between the concepts of «living strength» and «practical ability to use information»:

«One of the pillars of 'living strength' is 'the disposition or ability to find one's own topics/problems ('kadai'), to learn by oneself, think for oneself, to actively judge and act and to improve problem solving'. In other words, this can be expressed as the ability to educate oneself and to actively solve problems. Another important element of 'living strength' is 'the ability to select the information one really needs from abundant information and to actively construct ones thoughts'. We hope that these abilities can be cultivated as a manifestation of 'the practical ability of information use' which is one of the aims of information education. Further, a '[person of] rich human nature who while measuring oneself cooperates with others, is considerate of others and can be emotionally affected', is the side of sensitivity, humanity, sociality. This side can be cultivated through the company of humans at home or at school and through real experience in nature and society. For these encounters communication and expression play an important role.»

The committee gives recommendations for creating curricula according to students' development stage (2.2):

In elementary school the focus should be on group life, playfulness, phantasy. Real experience is most important in this stage. So a first playful acquaintance with information devices should be arranged, then the devices can be used for problem solving, later also

\footnotetext{
${ }^{30}$ «Jouhouka no shinten ni taiou shita shotou chuutou kyouiku ni okeru jouhou kyouiku no suishin nado ni kansuru chousa kenkyuu kyouryokusha kaigi»; literally: «Research Council on the Promotion of Information Education in Primary and Secondary Education in Response to Progressing Informatisation»

31 'jouhou katsuyou no jissenryoku'

32 'jouhou no kagakuteki na rikai'

33 'jouhou shakai ni sankaku suru taido', literally: «attitude to participate in planning of the information society»
} 
for abstraction and process oriented thinking. Students shall learn to chose from different information and devices for problem solving and evaluate the result.

Information education in middle school will be more theoretical/abstract. Here the individual should be able to chose not only his/her topics of interest and the means to work on them, but also between different areas of theoretical content in the field of information science. They shall be encouraged to research their topics actively, to organise the content and present it.

In high school we should find even more differentiation, as this is the stage when students' individual character develops more clearly and one of the central questions is to decide about one's future course. On the one hand more basics shall be taught, but there should also be more room for individual, specialised projects related to this particular development stage.

As for the Internet, «information and communication networks» are being mentioned on par with computers frequently and as a matter of course throughout the document as today's representative information devices. Networks are especially mentioned when it comes to topics like collection and transmission of information, communication with others and participation in the information society. In the outlook the authors also state their hope that in the near future all schools will be connected to the Internet.

«Multimedia» technology also has its place in the document besides other information devices and networks. e.g. in a paragraph on concrete examples for «scientific understanding of information» we find: «methods of expressing information as effectively as possible by using multimedia such as words, sounds or images, in accordance to the information one wishes to communicate and in consideration of the recipient's situation; methods of expressing the relations between phenomena by using formula, figures, tables, algorithms (procedures) etc.» or «methods of information processing that allow effective, efficient and highly precise processing and design of textual, numerical and image data». Altogether «multimedia» seems to be treated as a subset of information technology.

\subsubsection{The Curriculum Council's Report (1998.07)}

In July 1998 the Curriculum Council delivered its report on the «National Curriculum Standards Reform» [Kyouiku Katei Shingikai 1998a] ${ }^{34}$, where measures towards information education became more concrete.

Under chapter «I.C. Basic principles regarding common issues to all stages of school education and all subjects» measures for information education are explained as follows: «Response to the information-oriented society: Consistent and systematic information education through all stages of school education will require sufficient improvement of related subjects and active use of computers in virtually every subject. Elementary schools will employ computers for children's learning activities in the 'Period for Integrated Study' and other classes. Lower secondary school will require students to learn the information basics including basic computer skills in industrial art and homemaking class. Upper secondary school will establish a new required subject area of 'Information Study' ${ }^{35}$ ».

In chapter IV.B the subject «Information Study» is described in more detail:

«a. Upper secondary school will establish a new general subject area, 'Information Study', as a required area. It aims at helping students develop ability to independently choose, process and send information by appropriately using such information devices as computers and information communication networks. It will also help develop sound mind to participate in the information-oriented society.

b. There will be three subjects established under the subject area of 'Information Study'.

\footnotetext{
${ }^{34}$ Japanese Original: [Kyouiku Katei Shingikai 1998b] is $238 \mathrm{~KB}$ big, the official English synopsis is $65 \mathrm{~KB}$; citations here from the English version

${ }^{35}$ The Japanese name of the subject «jouhou» means «information», in official English translations the subject is mostly called «information study».
} 
The one is 'Information A' on the use of a computer and information communication networks. Another is 'Information B' that is for the scientific understanding of the functions and mechanism of a computer. The other is 'Information $C$ ' on the role and influence of information communication networks on the society. Students can choose one among them.»

The new Course of Study [Monbushou 1999a], where these recommendations are implemented, has been published in 1998-99. It will be put into practice from 2002 onwards (Course of Study implementation $2002 \mathrm{ff}^{36}$ ).

\subsubsection{Curriculum for the High School Subject «Information» (1999.03)}

This curriculum [Monbushou 1999b] is part of the Course of Study published in March 1999 (the high school curriculum is the last step to be implemented: from April 2003 onwards). The document is divided into the three sub-subjects «Information A», «Information $\mathrm{B}$ » and «Information $\mathrm{C}$ », from which students can chose. Under each category we find, clearly structured, the aims of this subject, the basic content and concrete advise how to teach this content at school and where to put special attention. Obviously the recommendations of the information education research council have been considered to a big extent.

The overall aim of the subject «Information» is stated as follows:

«To develop [in students] a scientific perspective and way of thinking about information through the acquisition of knowledge ('chishiki') and skills ('ginou') to use information and information technology; to let [them] understand the role and influence of information and information technology within society; and to foster the ability and attitude to actively accommodate the progressing informatisation.»

The three branches «Information A, B, C» each serve the same overall purpose of making students familiar with the basic handling of information devices (computers, information and communication networks etc.), introducing them to a scientific understanding of information (as in informatics or information science) and to cultivate an attitude of participation in the information society (e.g. through networked communication), but the main focus is on either one of these areas (cf. [Kyouiku Katei Shingikai 1998a]).

In Information A we find as the main content categories:

- «Scheme and information devices for using information» (incl. planning of problem solving and communicating information)

- «Collecting and distributing ('hasshin') information and the use of information devices» (incl. information search, collection, presentation and distribution and problems related to collection and distribution)

- «Integrated information processing and the use of computers» (incl. representation and different formats)

- «Development of information devices and changing lifestyle» (incl. construction of information devices, history of development, influence of informatisation on life and active participation in the information society)

Information B concentrates on:

- «Problem solving and computer use» (incl. problem solving procedures, strengths and weaknesses of automated information processing)

\footnotetext{
${ }^{36}$ http://www.monbu.go.jp/series/00000056/gif/mokuji2.gif (Course of Study implementation 2002ff)
} 
- «Construction and function of computers» (incl. digitisation and different representations of information, processing mechanisms, simple algorithms, designing representation and processing)

- «Problem modelling and solving with the help of computers» (incl. modelling, simulation, databases)

- «Information technology sustaining the information society» (incl. IT for measurement and control, human needs with respect to IT, IT influence on society)

Information $\mathrm{C}$ has the items:

- «Digitisation of information» (incl. mechanism of digitisation, types and features of information devices, methods of presenting information with information devices)

- «Information networks and communication» (incl. construction of networks, effective methods for transmitting information, use of networks for communication)

- «Collection and distribution of information and individual responsibility» (incl. publishing and protection of information, individual responsibility, information collection and distribution through networks)

- «Progress of informatisation and its influence on society» (incl. information systems and society, influence of informatisation on society) ${ }^{37}$

Though not named explicity as «Internet» the role of «information and communication networks» is a very important one in this curriculum. In the overall aims of «Information $\mathrm{A} »$ and «Information $\mathrm{C}$ » understanding and skilful use of «information and communication networks» is explicitly mentioned along with computers or «information devices» in general. In the detailed description within A-C networks are mentioned as means for problem solving, communication of content, information search and collection as well as providing of content, and participation in the information society. As Information $C$ focuses especially on networks, here their technical construction is also dealt with. Further on communication over networks and related issues like efficient communication, handling of email and electronic conferencing software, security and privacy considerations receive special attention.

\subsection{Summary of Key Concepts in Japan}

Recent Japanese general vision documents as well as special topic investigations in educational policy focus on «information education» rather than on «media». The concepts of «information literacy» as the aim of «information education» has been systematically developed since the middle of the 1980s . Already in 1986 the main components of information literacy were seen to be information selection and use according to one's own purposes, information production and communication, and information morale. Today the main elements repeatedly mentioned are: practical information (technology) use, scientific understanding of information, and active participation in the information society. These three categories and their elements have been systematised especially by the Information Education Research Council in 1997.

Further we find an explicit theoretical connection of »information literacy» and the main educational goal of «living strength». Response to the information society is seen as an important pillar of educational reform.

\footnotetext{
${ }^{37}$ I have made a complete English translation available under http: / / www. gmd. de/People/Irene. Langner/docs/200107/jouhou.html. The location might change, but the document should remain retrievable with the meta keys «Japanese high school curriculum Jouhou»
} 
If we look at the concrete suggestions for different school grades, the idea is to create curricula that gradually shift focus from group life to more individuality, from concrete experience to abstract and theoretic analysis, and from common problems to personal interests. In the subject «information» all high school students will soon learn about the construction of IT devices, principles of information representation and processing, using computers and networks for different purposes, and social implications of information technology.

Concrete Internet applications are recommended for all grades starting with elementary school. Functions like information search, communication and cooperation are mentioned particularly often. However, although strong emphasis is put on responses to the information society, Internet use will for the time being actually only be enforced in high school through the subject «information». The «period for integrated learning» in lower grades leaves room for network use, but it will be up to the individual schools and teachers to fill this space with appropriate content. The unit on «information basics» in the subject technology is an optional one. So the actual implementation of Internet literacy education in lower grades remains uncertain.

\section{Media Competence and the Internet in German Educa- tional Guidelines}

\subsection{Information Technology and Media Education before 1995}

\subsubsection{Media Education}

According to Baacke, the notion of «media competence» developed in German pedagogics around the end of the 1960s, beginning of the 1970s. Before the 1960s mass media had been viewed by educators mainly as dangerous for children's socialisation, and accordingly defence and protection were the main reactions. During the 1960s, with the diffusion of TV and its increased influence on society, critical media theories evolved. Media education at that time aimed at raising consciousness for the conditions of media content production, at emancipation of the individual, promoting students' self-determination and chances of participation. Media education became action oriented, the previous «recipient» became a «user», and possibly also a «producer» (e.g. in the video movement). This development made a certain acceptance of media possible [Baacke 1996, 112f].

The idea of «media competence», as it has been elaborated in Germany since the 1970s, is not restricted to functional «ability» or «qualification», but also incorporates theories of democracy and communication [Baacke 1998, 25]. The theorem of «competence» goes back to Chomsky's postulate, that every human has the innate competence to use language and signs, i.e. it is a postulate of basic equality. Applied to media education this means: «Every human being is in principle a 'mature recipient', at the same time, as a being with communicative competence, it is also an active media user, thus has to be able (and the technical instruments for this purpose have to be made available to it!) to express itself through media.» [Baacke 1996, 117]. «Media competence» is «the ability to include among others all sorts of media into one's repertoire of communication and action, while actively appropriating the world» [Baacke 1996, 119]. Later, Baacke further elaborated his view of «media competence» with the four main aspects «media critique», «media study», «media use» and «media creation» ${ }^{38}$, and this scheme is broadly cited in German academic media pedagogics. In some of the federal recommendations for media education we also find these aspects (mostly less systematically).

Media education up to the 1990s mainly was conducted in subjects like German, later also in art, music, or politics. It mainly dealt with media messages from literature, radio or

\footnotetext{
${ }^{38}$ «Medienkritik, Medienkunde, Mediennutzung, Mediengestaltung»
} 
television [Schelhowe 1998]. The first official guideline on the federal level devoted entirely to media education ${ }^{39}$, is the BLK framework from 1995 [Bund-Länder-Kommission für Bildungsplanung und Forschungsförderung (BLK) 1995]. Here the «media world» is characterised as an «educational world of its own» which school has to react to. At that time the «new electronic media» had already entered the scene.

\subsubsection{Basic Information Technology Education}

«Basic information technology education» («Informationstechnische Grundbildung», ITG) is a topic dealt with on the federal level since the middle of the 1980s. In 1984, under the impression of the diffusion of PCs to all areas of society, the BLK issued a framework for «Information technology education in school and professional education» ${ }^{40}$. In 1987, together with other documents, it published an «Overall Concept for IT Education $»^{41}$ [BundLänder-Kommission für Bildungsplanung und Forschungsförderung 1987]. The idea was to integrate elements of ITG into existing subjects in order to give every student access to new technology and media and at the same time prevent risks related to inappropriate use. For extended study of this area in higher grades the subject informatics was recommended. According to this framework ITG's main tasks are:

- examination and categorisation of individual experiences with information technology

- teaching basic structures and terminology in the field of information technology

- introduction into handling of computers and their peripherals

- teaching knowledge about possible applications and control of information technology

- introduction into algorithmic representations of problem solving

- insight into the development of electronic data processing

- creating awareness for social and economic effects of the diffusion of microelectronics

- presenting chances and risks of information technology, building up a rational attitude towards the technology

- introduction into problems of privacy and data protection [Bund-Länder-Kommission für Bildungsplanung und Forschungsförderung 1987, 11-12]

Thus ITG aims at a basic understanding of structures and history of IT, understanding (some) basic principles of information processing, computer handling skills, knowledge about applications, limitations, risks and social effects of IT, understanding of privacy and data protection, a rational attitude towards and conscious life with IT.

With respect to the media aspect the paper also states that «dealing with the computer and other information and communication technology poses demands to media education that exceed the hitherto common practice in the area of traditional audiovisual media». Media education has the task to convey the ability

- to perceive media exactly

- to critically assess media

- to chose and use media according to certain aims

\footnotetext{
${ }^{39}$ judging from the publication indices under http://www.blk-bonn. de/veroeffentlichungen. htm and http: //www. kmk. org/doc/publ/pub.htm

40 "Informationstechnische Bildung in Schule und Ausbildung"

41 "Gesamtkonzept für die informationstechnische Bildung"
} 
Computer related media education has to convey an «adequate and responsible attitude». It has to enable students to «a conscious use of computers as a tool for information retrieval, for research, storing and processing of information. It also has to include the various creative and playful possibilities as well as the chances of different forms of interaction and cooperation at school and in class» [Bund-Länder-Kommission für Bildungsplanung und Forschungsförderung 1987, 29-32].

In the following years the states developed different approaches to ITG, or «IKG» («basic information and communication education»): some tied ITG to certain key subjects (e.g. Bavaria), others experimented with ITG as an integrative topic (e.g. NRW, Hesse, Hamburg), Lower Saxony introduced a model of extensive subject integration, and Saxony later created a subject «applied informatics» for middle schools. Most states elaborated ITG concepts containing 60-80 hours of compulsory ITG education, centring around grade 8 (cf. [Tully 1994, 165]).

But whatever the organisational approach was, most of them had considerable difficulties with the implementation, e.g. because of lacking hardware or personnel, organisational problems with integrative topics, insufficient teacher training, lack of interest on the part of subject teachers, or because school principals did not recognise a need for cooperation. Hauf-Tulodziecki states in April 1996, that it probably «still will be a long way in all states until ITG becomes a natural part of school teaching» [Hauf-Tulodziecki 1996]. Or, as Schulz-Zander puts it in 1998: «Although the «Informationstechnische Grundbildung» is a compulsory part of school curricula in all states it has not been yet put into practice in all schools. In NRW about one third of students receive ICT Education. The key problem is probably the lack of qualified teachers teaching in this new field.» [Schulz-Zander 1998a, 12]. And Wilkens concludes from several reports that the states have not succeeded in «implementing ITG into school practice to the planned extent and with the intended explicity» [Wilkens 2000, 38]. Although the BLK concept had already seen the tool as well as the medium aspect of information technology, the system could not appropriate the task of fully implementing the concept.

\subsubsection{The Subject Informatics}

The optional subject informatics entered German general schools in the 1970s and has been «implemented broadly in upper secondary education during the 80's. In general, it can be chosen from grade 11 through grade 13. In some states, as in North-Rhine-Westphalia (NRW), it can be taken in grade 9 and 10, too» [Schulz-Zander 1998a, 11]. Until the middle of the 1980s the subject focused on the notion of algorithms for problem solving. With the diffusion of personal computers with graphic user interfaces and easy to handle applications during the following years, though, awareness rose that this approach was too narrow for a contribution to general education. Until the beginning of the 1990s a perspective was developed that included three aspects of informatics: man-computer interaction, formalisation and automation of brain-work, and information systems, society and environment [Wilkens 2000, 48-50]. Nevertheless, no broad consensus within society about the content and status of the subject could be reached, and at the end of the 1990s observers still talk about the «crisis» of the subject (e.g. [Schulz-Zander 1998a, 11]). According to a Bavarian brochure on informatics education, curricula of school informatics are still in the development stage of the late 1980s [Zentralstelle für Computer im Unterricht 2000].

\subsection{Recent Guidelines and Suggestions}

On the federal level since 1995 BLK and KMK have published three documents related to our area of interest: The BLK «Orientation Framework for Media Education at School» 
from 1995, the KMK «Declaration on Media Education at School» from May 1995, and KMK's «New Media and Telecommunication in Education» from February 1997. There has been no federal recommendation on the topic of information or informatics education at school since that time ${ }^{42}$.

On the state level procedures and time cycles of revising curricula differ, so the guidelines for basic information, informatics and media education are in different stages of development. For my analysis I have chosen examples from four bigger states that belong to different regions and political orientations and which made the relevant documents available online. Besides recommendations on ITG or media education for lower grades, curricula for informatics in grade 11-13 were most likely to deal with Internet related topics to a certain extent, so examples from Gymnasium guidelines are overrepresented here.

\subsubsection{BLK's Orientation Framework for Media Education (1995)}

After the 1989 recommendations for ITG, the «Orientation Framework for Media Education at School» from 1995 [Bund-Länder-Kommission für Bildungsplanung und Forschungsförderung (BLK) 1995] was the first (and is to date the last) systematic attempt of the BLK to define a role for the new «electronic media» at school.

While the document says in its introduction «This framework focuses on electronic media» ${ }^{43}$, the definition of «electronic media» remains vague. The phrase «press, radio, film as well as electronic media» and the following mentioning of «networked computer and video systems» and «multimedia» point to a meaning somewhere along the lines of «computers, multimedia and networks.» Nevertheless, the biggest part of the document in fact does not deal explicitly with those «new» media. On the one hand we can suppose that at that time the impact of the Internet had not yet become clear. On the other hand the authors also give a principle reason for not concentrating on particular media:

«Media education - especially when it considers the technical development - cannot adapt to the emergence or dominance of particular media, e.g. television. It has to be designed in a way that it does not have to be rewritten, when the supply structures change. Rather one of the most important points of reference for media education is the question, whether and possibly how relatively constant user needs, e.g. the need for care, for social acceptance, for orientation and security, experience specific shaping or qualitative change through media. In this sense media education should be designed in a way that it well escorts and includes the changes in the media sector, but does so on the basis of some fundamental principles that are oriented to the ideas and experiences of children and young people.» (I.2)

The principles mentioned are:

- Media education has to follow the overall educational aim of enabling students to act «adequately, in a self-determined way, creatively and socially responsibly» ${ }^{44}$.

- Media education has to be conducted according to the circumstances in which the students live, according to their communicative environment, their needs and stage of development and experience $^{45}$.

- Media education has to be situation oriented, experience oriented (including senses and emotions), action oriented (processes of problem solving, decision making, evaluation and creation), needs oriented, communication oriented, and development oriented.

\footnotetext{
${ }^{42}$ Further, a couple of model projects have been conducted. e.g. in the name of the model project SEMIK ("Systematische Einbeziehung von Medien, Informations- und Kommunikationstechnologien in Lehr- und Lernprozesse": «Systematic incorporation of media, information and communication technology into processes of teaching and learning», 1998-2003) a certain differentiation can be seen. But these model projects have not resulted in formal recommendations yet, and I confine my investigation to the latter here.

43 «Der Orientierungsrahmen befaßt sich schwerpunktmäßig mit den elektronischen Medien.»

44 «ein sachgerechtes, selbstbestimmtes und kreatives Handeln in sozialer Verantwortung»

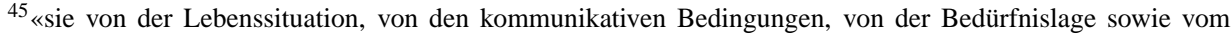
jeweils gegebenen Entwicklungs- und Erfahrungsstand ausgehen muß»
} 
On this basis the task of school is to inspire students for and and support them with

- media use

- dealing with media influence

- discriminating and analysing media messages

- media production

with the aim of enabling them to participation in the creation of «media culture».

The three main areas suggested for media education at school are:

- use of media and non-media means for different tasks

- insight into functions of media and the conditions of their production

- working with media practically and creatively

Computers and networks are mentioned rather in passing and not with reference to a characteristic role, which is in accordance to the above statement, that particular media do not change the overall approach. While certainly some basic human needs do not change through the development of technology, it remains unsatisfying that the recommendations have not been reviewed since 1995. Because the background scenario is too much characterised through individual recipients in the face of overwhelming mass media, the increased possibilities of active many-to-many communication and the need for basic understanding of information processing does not receive due attention. Wilkens' evaluation goes in a similar direction: «It remains uncertain, whether the task to dialectically relate the two aspects - the instrumental and the medial character of information technology - to each other within the framework of the current concept of media education.» [Wilkens 2000, 44].

\subsubsection{KMK's Declarations from 1995 and 1997}

In the 1995 declaration [Ständige Konferenz der Kultusminister der Länder in der Bundesrepublik Deutschland 1995] the ministers of education, under reference to the BLK Orientation Framework, agree that media education has to aim at «enabling students to deal with media adequately, in a self-determined way and socially responsibly». For this purpose it is held necessary that students shall:

- «find their way in the world of media, i.e. that they know the variety of media, that they perceive the diverse interconnections (with respect to content as well as technically) between the media, that they get access, practice their handling and learn to chose and use them in a meaningful way.»

- «can critically assess the information, experiences and action patterns conveyed by the media, i.e. that they can examine their reality and relate them to the social functions of media and the economic conditions of their production and distribution»

- «can act self-confidently, responsibly and productively in a world determined by media, i.e. that they develop aesthetic and moral standards, build up creative abilities besides the analytic ones and learn through practical media work to express their own ideas and interests as well as to make them public».

The three pillars mentioned here could be summarised under the categories of media knowledge and handling, critical attitude and understanding of connections, and competent action in the media-dominated world. 
The 1997 resolution [Ständige Konferenz der Kultusminister der Länder in der Bundesrepublik Deutschland 1997] reflects more insights into the changes brought about through computer networks. Possibilities of information and communication networks are explicitly mentioned, e.g. access to data, worldwide communication, independent learning and academic cooperation, storing and processing capacities, interactive and virtual reality applications. With respect to the Internet we find the view that learners can be enabled to a more independent organisation of their learning activities through the use of the Internet and other information systems. On the other hand access to «dangerous content», flooding with information and possibilities for manipulation are also associated with the use of networks. The connection of schools to the Internet is discussed briefly.

Also, «comprehensive media competence», including topics previously mainly associated with ITG, is stated as one of the central goals of media education: «Through the testing, examination and implementation of new media, multimedia and telecommunication within the educational system, questions can be consolidated and expanded that so far have been dealt with in connection with media education on the one hand and information technology education on the other hand. The connection of aspects from both areas are a decisive factor for comprehensive media competence, i.e. for enabling to a responsible and creative use of new media.» (p. 5)

Systematically speaking, the KMK sees four different roles for «new media» in education: as an object of teaching and learning, as a tool for teaching and learning, as a field for professional qualification and as a means for distance and further education. School education is especially mentioned in the first two aspects.

\subsubsection{Bavaria}

Bavaria put the BLK's ITG guidelines into practice in 1988/89 [Tully 1994, 165]. The general aims listed in the Bavarian framework for ITG [Bayrisches Staatsministerium für Unterricht, Kultus, Wissenschaft und Kunst 1995, 51f] follow the BLK recommendations closely. In the 1995 «General programme for information technology education at school» «recent developments» are already taken into account, e.g. educational use of Btx, Datex-J, an "Information System School Education and Computer" (ISBC), mailboxes, the "Bavarian Schoolnet" with connection to the Internet, Compuserve trials, or amateur packet radio are mentioned, along with databases and multimedia applications [Bayrisches Staatsministerium für Unterricht, Kultus, Wissenschaft und Kunst 1995, 25-27].

An interesting Bavarian document is the brochure «Informatics at School», published by the «Central Agency for Computers at School» [Zentralstelle für Computer im Unterricht 2000]. Its aim is to give guidance for a more current informatics education in general schools within the framework of existing curricula. I.e. the fact that curricula do not change quickly enough and that teachers need guidance to deal with new content under old curricula is explicitly acknowledged here.

The document demands, that not only mere usage aspects, but "a deep structural understanding of the basics of technology used has to be an integral element of general education". I.e. certain informatics content is held necessary for a contemporary general education. Daily life examples given are the competent use of expert systems, Internet search engines or office work-flow systems.

Three leading questions for structuring informatics education are listed: «How can information systems solve problems in everyday life? How are information systems organised? What are the basics and limits of technical information processing?» As for central content, most informatics topics are said to deal with questions of representation and modelling. Further, social and legal questions of information processing and information systems use are also mentioned, but not given special priority here.

Internet applications are naturally integrated into the suggested content: e.g. knowledge about protocols and client-server architecture of email and WWW, access rights, direc- 
tory structure and security strategies, information search, document transfer, downloads and publishing, HTML, data protection, copyright and protection of young people on the Internet are among the topics mentioned.

Altogether, the focus of the suggested informatics content centres around information processing. Modern examples like Internet applications are well integrated, but the subject does not cover media related and social aspects to a big extent. Thus, desirable Internet related content is only partly considered here. On the web page on Bavarian curricula ${ }^{46}$ we find references to informatics and ITB, but non to media education guidelines.

\subsubsection{Hesse}

The Hessian «frameworks» for media education ${ }^{47}$ and $\mathrm{IKG}^{48}$ that are available online, are currently in the state of drafts and thus not considered here.

Hesse's informatics curriculum for grades 11-13, Gymnasium, from 1994 [Hessisches Kultusministerium 1994] concentrates more on social aspects than the Bavarian one: Informatics education is said to play an important role for general education in that it helps to understand central current problems of society and helps to prepare for dealing with future ways of life (p. 3). The basic tasks of informatics education are listed as:

- "Personality development of the individual through promoting his/her ability to judge and act as well as his/her responsible dealing with information and technology. The computer shall be experienced as a tool that supplements and enhances human capacities, that changes human work and has manifold effects on the users."

- "Teaching of theoretical and technical basics of information and communication technology and their contribution to the development of culture and science."

- "Creating awareness ("Sensibilisierung") for problems accompanying the development of the information society as a social key problem of concern to all of us" (p. 3f)

Compulsory are the topic areas: «Tools and methods for problem solving», «Universal symbol processing machine - man and machine», and «Information and communication systems within society and environment» (p. 9). The following topics are seen as the main contribution of informatics to general education: analysis, description and modelling of complex systems; methods of problem solving and their evaluation; reflection about the relations of man and technology; responsible use of information and communication technology; promotion of creative thinking and attitude towards work; fostering of the ability to communicate and cooperate (p. 5f).

The Internet is not mentioned (yet), but «networks» (in a technical sense) or «networked and open systems» (as a social factor) are mentioned in a very general way.

\subsubsection{North Rhine-Westphalia (NRW)}

On NRW's educational server Internet topics and $\mathrm{IKG}^{49}$ are mostly treated under the category «new media». No detailed IKG guidelines are available at the curricula server ${ }^{50}$ or the educational server, but a short explanation on ITG ${ }^{51}$ from Oct. 1996 tells us that there are three main topic areas:

\footnotetext{
${ }^{46}$ http: //www.isb.bayern.de/bf/isbl/index.htm (Bavarian curricula)

${ }^{47}$ http: //www.bildung.hessen.de/abereich/rplan/index 4 .htm (media education)

${ }^{48}$ http: //www.bildung.hessen.de/abereich/rplan/index3.htm (IKG)

${ }^{49}$ http://www.learn-line.nrw.de/angebote/neuemedien/medio/ikg/ikg.htm (IKG)

${ }^{50}$ http://www.schul-welt.de/verlag/schulwelt/ (curricula server)

${ }^{51}$ http://www.learn-line.nrw.de/angebote/modell/bevchina/china2.htm (explanation on ITG )
} 
- word processing, file management, calculation

- process data processing, modelling and simulation

- new communication technologies in public data networks [to be included in a new version of the guidelines]

The 1999 informatics curriculum for Gymnasium grades 11-13 in NRW [Ministerium für Schule und Weiterbildung, Wissenschaft und Forschung des Landes Nordrhein-Westfalen 99 1] substitutes the 1981 version. Concerning computer and media education in general it states: «In reaction to the extensive use of computers and modern procedures for collecting and processing information, school has taken on the task to establish carefully targeted computer use as a current Kulturtechnik in the school subjects and to teach it within a well-pondered framework of media education» (p. 6). First of all this happens within ITG, whereas informatics goes beyond these basics in that it develops «procedures, models and overall principles of efficient information processing». Informatics provides «tools for thought» («Denk-Zeug») for solutions to «various and complex problems» in our environment (p. 5). In other words, the authors take an integrated perspective on information technology and media education.

The curriculum talks more about tasks and concrete topics than general aims of informatics, but the following aims can be found: Giving students «tools for thought» and for problem solving; enabling students to study (informatics) at university; conveying theories and facts in the context of applications with appropriate methodology; fostering stringent thinking, creativity and intellectual flexibility through practising strategy development; enhancing team work and cooperation abilities through software development projects; developing the ability to judge and assess appropriate computer use and effects on society; giving integrative perspectives through appropriate combination with other subject content; contributing to media competence (p. 6-9).

The Internet plays an important role in many of the application scenarios mentioned: e.g. querying information systems like search engines; data exchange from local to global scale - technical questions and social implications; databases, expert systems, computer search («Rasterfahndung») and data protection; WWW and email log-files as examples for data structures that can be analysed and connections to privacy issues; network structures and global network applications; setting up an Internet based service as a project work; individual research papers e.g. on information organisation within an Internet presentation; city administration online; cryptology and electronic money.

Altogether NRW emphasises media education and provides teachers with a lot of material, including some on «new media». High school informatics aims at integrating information processing and social aspects and includes Internet related topics, but for lower grades it is not clear whether students can expect a basic education which includes the Internet and information processing basics.

\subsubsection{Thuringia}

Thuringia as one of the former East German states went through a far-reaching curricular reform since 1990. The 1999 curricula deal with media use 1. as one element of contemporary didactic principles and methods. 2. «use of media and information technology» $\left(\mathrm{UMI}^{52}\right.$ ) belongs to the special integrative topics ${ }^{53}$ all general schools have to cover [Thüringer Kultusministerium 1999, intro]. The new priorities are explained as follows: First of all, a modern general education has to develop in students learning competence. Further, in an «increasingly confusing world» students need the «faculty of individual

\footnotetext{
52 «Umgang mit Medien und Informationstechniken»

53 «fächerübergreifende Themen»
} 
judgement characterised through ethics of responsibility, more orientation knowledge instead of even more factual knowledge ('Verfügungswissen'), ability for multi-perspective and networked thinking, and models for a changed lifestyle. Integrative topics can help to combine school learning with real life problems.» [Thüringer Institut für Lehrerfortbildung, Lehrplanentwicklung und Medien (ThILLM) 1999, 4].

The aims of UMI are: «UMI shall help young people to critically assess communication and media services and to consciously use them. The development of abilities for research, selection, adoption and critical assessment shall guarantee that students can deal with the growing media supply in a self-confident and appropriate way. Students shall experience media as a chance for developing their personality, but also recognise the risks and dangers that can arise through false media use.» «UMI aims at enabling students to an adequate, self-determined and socially responsible use of media. The development of media competence is a lifelong process, school has to support.» (p. 8f).

Altogether the Thuringian UMI recommendations reflect the focus of the BLK framework from 1995, but add «experiences with information and communication technology», including the Internet, to the concrete media examples. They suggest these technologies as tools for «practice (writing, calculating); word processing; data management, e.g. electronic library; analysis and presentation of data in diagrams; help with drawing and construction, simulation of static and dynamic systems; process steering and control; and diverse communication (multimedia)» (p. 10). In other words, information processing related topics are integrated into the media perspective. On the other hand, ITG (especially «computer related abilities and skills» (p. 21) ) is mentioned in a separate chapter, so obviously the historical separation of the two worlds has not completely been overcome even in this well researched and modern curriculum.

The informatics curriculum for Gymnasium (grades 9-12) from 1999 [Thüringer Kultusministerium 1999] explains the different competencies to be developed within the subject informatics:

- a) «Factual competence» includes «knowledge about principles and methods of informatics like modelling, modularisation, structuring»; «problem solving abilities through the use of informatics tools and processes»; «retrieval, exchange and processing of information with the help of modern information and communication systems»; knowledge about problems that cannot be solved with computers

- b) «Methodical competence» comprises the application of «methods of modern software development»; «choice of information systems for problem solving»; planning and organising of problem solving, documentation and presentation of the results; acquiring and using necessary knowledge across subject borders

- c) «Social competence» involves developing «strategies for collaborative learning and working», especially within project work; and taking on responsibility for the joint work and its presentation

- d) «Self competence» has to do with the «insight that information and communication technology has manifold effects on our life» and that this fact «constitutes a special responsibility towards people, society and nature»; students recognise their «responsibility for planning and untiringly carrying through their work together with a partner or a group»; they «critically assess» their own work (p. 7)

The areas where these competencies should be acquired are: «Dealing with information», «Functions of information systems», «Problem solving with the help of information systems», and «Effects of informatics on the individual and society» (p. 8-9).

Internet topics play a prominent role in the examples given: HTML is one of the languages held suitable for the introduction into informatics. The unit on «communication in networks» contains topics like: trends of social development, representation of information (digitisation, binary code, mailbox, Internet, online services, WWW as an Internet 
service, search strategies and search services on the Internet, online databases, Thuringia School Computer Network, data compression), structure of computer networks, data protection in the public and private sphere as protection of a basic right (informational selfdetermination, various individual rights, data protection guidelines, data protection problems on the Internet), data security requirements (appropriateness, confidentiality, authenticity, integrity, anonymity, data protection technology), different encryption methods.

Altogether the documents available for Thuringian informatics and media education reflect a modern approach that integrates media and informatics aspects as well as important Internet examples, be it under the umbrella of «UMI» or «informatics» for higher grades.

\subsection{Summary of Key Concepts in Germany}

In the German educational guidelines and curricula we find a clear development over time: from treating information technology education (focusing on computers) and media education (focusing on broadcast media) as two different things towards ideas of integrating the two areas, promoted through the development of multimedia applications and computer networks, which can be seen as both, information processing devices and media.

Key concepts for information technology education are: basic understanding of information processing and structures of information technology; basic handling of computers and programmes and knowledge of different applications; knowledge about the history, chances, risks, social and economic effects of information technology; analysing individual experiences with the technology and facilitating a rational attitude.

The key concepts of the BLK media education paper of 1995 are: adequate, self-determined, creative and socially responsible media use; use of media and other means as tools for different tasks, insight into functions of media and the conditions of their production, working with media practically and creatively; i.e. media knowledge, media use, media assessment (critique), and media creation.

This tenor is strongly reflected in followup guidelines of the states. The more recent Länder recommendations like Thuringias «media and information technology education» for all grades and also some of the informatics guidelines for higher grades show approaches of integrating information technology elements including the Internet into their media education concepts. However, the impression remains, that this integration still needs work towards convincing systematisations.

Naturally, informatics curricula take a more information processing oriented approach, but also from this side contributions towards an integration of media and information technology education can be seen. Here we also find the clearest statements about information technology topics as a necessary part of general education. Computers and networks are often given the status of Kulturtechniken. Concrete concepts mentioned as important for general education are representation and modelling of information, analysis of complex systems, problem structuring and solving, evaluation of different approaches, insights into interactions between technology, individual and society, increased possibilities, need for responsible use and prevention of misuse, new modes of communication and cooperation, fostering thinking, creativity, faculty of judgement and flexibility.

Some approaches of integrating Internet topics into the recommendations for media education in all grades can be seen. Especially the increased possibilities for worldwide communication and cooperation are mentioned. Information search and electronic libraries are further examples.

The Informatics curricula view the Internet from a technical as well as a social perspective. Examples include protocols, information architecture or encryption on one hand and communication and privacy protection on the other. Most topics have both components, e.g. web publishing, search strategies, log file analysis. Nevertheless, the elements of Internet knowledge and skills that should be part of general education are not clearly elaborated. 
Regardless of single advanced approaches, overall no agreed upon content with respect to the Internet can be stated - especially not for lower secondary education. Certain Internet applications are integrated into the different areas of informatics or they are mentioned in passing in media education guidelines, but a deep analysis of the differences compared with older media and an adequate curriculum development is missing.

\section{Comparison and Suggestions}

\subsection{Common Tasks, Different Foci}

Across the cultural distance we can find similarities with respect to general educational aims such as self-determination, participation and responsibility as well as to particular aims in the area of media and information technology: e.g. skilful use of information technology and/or media for one's own purposes, the ability to select and judge, and an active and responsible attitude. The central tripartite goal phrases for information rsp. media education all contain elements of practical use, understanding, and participation: The BLK concept of media education consists of 1 . use of media and non-media means for different tasks, 2. insight into functions of media and the conditions of their production, and 3 . working with media practically and creatively. KMK aims at 1 . media knowledge and handling, 2. critical attitude and understanding of connections, and 3. competent action in the media-dominated world. The mainstream Japanese concept of information literacy includes 1 . practical information use, 2. scientific understanding of information, and 3. active participation in the information society. The explicit or implicit notion of computers and networks as Kulturtechniken is spreading. In both countries the guidelines also use terms that refer to innate human capabilities («competence» rsp. «shishitsu»). Over time we can state a priority change from factual to procedural knowledge, from discipline orientation to an integration of topics, and from static to more flexible curricula and increased local responsibility.

In most of the reviewed guidelines for lower school grades in both countries I have not found compulsory content with respect to information technology and media in general and for Internet related topics in particular. This is a serious lack, because in lower secondary grades students usually start to use the technology at home or in public spaces, so competent guidance oriented towards individual needs would be especially desirable.

Differences can be found with respect to treating Internet use within the key concepts of «information» vs. «media» and with respect to the popularity of those concepts in the course of the last 20 years:

In Japan from the middle of the 1980s up to the present «information literacy» has been the key concept in our area of interest. Recently, «old» media are hardly mentioned any more, and «new» media are mostly subsumed to information technology. The importance of the Internet is emphasised earlier and more often than in German guidelines and at least all high school students will receive Internet related education from 2003 onwards. The determination to conduct systematic «information education» as a part of general education has resulted in the creation of the new subject «information». The name shows the concentration on the phenomenon of information itself, and technology is only one (if a prominent) aspect ${ }^{54}$. General relations between technology and society are treated in the middle school subject «technology and home economics». The biggest proportion of content for the subject «information» consists of understanding of possibilities and procedures, functional and practical aspects.

One reason for the Japanese focus on information can be seen in Japan's history of eager

\footnotetext{
${ }^{54} \mathrm{cf}$. the contrast to names of institutions like the academic «Information Processing Society» («Jouhou Shori Gakkai») or the National Institute of Informatics («Kokuritsu Jouhougaku Kenkyuusho»)
} 
information collection from ancient times on [Pauer 1996, 13f], partly due to geopolitical factors .

In Germany recent federal educational policy and also state policy for lower grades have been concentrating on «media competence». Especially the critical, emancipation oriented and creative approach towards media cannot be found that explicitly in Japanese guidelines. One reason can be supposed to be the fact, that in Germany the country's nationalistic past, including the role of media for Nazi propaganda, has been more thoroughly examined after the war than in Japan.

The BLK framework from 1995 (and following state recommendations) subsumes computers and networks to «media», although information technology education exists as a topic area of its own since the late 1980s. It seems that not much use has been made of the relevant expertise from the school subject informatics either in creating modern concepts for general education. Media education, concerned with critical and creative use of media, and informatics education for higher school grades, which for a long time concentrated on a narrow computer science approach and in particular programming, remained separated worlds. Meanwhile however, informatics curricula in the states have partly reacted to the technological change. Since the late 1990s, also on the federal level, calls for a more systematic integration of information technology and media education have become stronger. Nevertheless, no compulsory Internet related content can be found yet.

\subsection{Suggestions for Integration}

The Internet challenges schools in a variety of ways, but it also provides chances for implementing reform pedagogic forms of learning and new role models for teachers and students. It can help to open up the schools and enrich content and personal encounters. In this sense Otani sees the «Internet as a Trojan horse for school education» [OOTANI Takashi 1997]. Other authors have called the Internet «a chance for a new learning culture» [Schulz-Zander 1998b] or a «motor for new didactics» [Lachmann 1998].

The net also urges us to systematically (re)assess the role of media and information technology for the individual and society. Here the different approaches analysed above have different strengths and weaknesses, e.g.:

The BLK framework rightly stresses the need for critical analysis of media messages and the conditions of their production. This view should be extended to the Internet, e.g. by watching closely the new power gained by large institutions and businesses through convenient mass data gathering and processing. On the other hand, its emphasis on emancipation from media prevents a fresh view on possibilities for emancipation with the help of media like the Internet: e.g. open source software (freely available strong encryption and many more examples) and access to the most diverse information sources enable the competent individual in an unprecedented way.

The Japanese approach for the subject «information» and modern German informatics curricula rightly stress the importance of understanding of information processing principles and systems for life in our contemporary society. These approaches should be further elaborated and implemented early on in general lower secondary education.

In both countries activation of the individual to participate in the information and media society is envisioned. But in order to see the possibilities and limits more clearly, the actual power factors have to be analysed more thoroughly on the basis of economic as well as technological knowledge.

The Japanese guidelines impress with their systematic explication of «information literacy». The German guidelines see functions of media and influences on the individual more clearly. The aim should be to more systematically integrate concepts of information (technology) and media education and to give the Internet a prominent status. Well elaborated suggestions are available, e.g. from the Society for Informatics (GI) Working 
Group on Informatics Education in Schools [Hauf-Tulodziecki 1999] or Wilkens [Wilkens 2000], suggestions on integration of Internet related content e.g. from Mötsch [Mötsch 1997, 68f] or Schulz-Zander [Schulz-Zander 1997]. The Japanese focus on information as such (and related recommendations made e.g. by the Society for Information Processing [Jouhou shori gakkai shotou chuutou jouhou kyouiku iinkai waakingu guruupu 1998] or Kurokami's interpretation of "jouhou"55) could give further ideas for a comprehensive approach.

\section{References}

Baacke, D. (1996). Medienkompetenz - Begrifflichkeit und sozialer Wandel (Media competence - terminology and social change). In A. von Rein (Ed.), Medienkompetenz als Schlüsselbegriff (Media competence as key concept), pp. 112-124. Bad Heilbrunn: Verlag Julius Klinkhardt.

Baacke, D. (1998). Medienkompetenz - Herkunft, Reichweite und strategische Bedeutung eines Begriffs (Media competence - origin, scope and strategic meaning of a term). In H. Kubicek et al. (Eds.), Lernort Multimedia (Multimedia as a site for learning), Jahrbuch Telekommunikation und Gesellschaft 1998, pp. 22-27. Heidelberg: R.v.Decker's Verlag.

Bayrisches Staatsministerium für Unterricht, Kultus, Wissenschaft und Kunst (Bavarian Ministry for Education, Culture, Science and Art) (1995, May). Gesamtkonzept für die Informationstechnische Bildung in der Schule. Fortschreibung 1995. Zwischenbilianz und Leitlinie für die weitere Arbeit. (General programme for information technology education at school. Revision of 1995. Provisional appraisal and guideline for further work.). München: Bayrisches Staatsministerium für Unterricht, Kultus, Wissenschaft und Kunst.

http://www.stmukwk.bayern.de/schule/itg/index.html

Bund-Länder-Kommission für Bildungsplanung und Forschungsförderung (Bund-LänderCommission for Educational Planning and Research Promotion) (1987). Gesamtkonzept für die informationstechnische Bildung (Overall concept for information technology education). Materialien zur Bildungsplanung Heft 16. Bonn: BLK.

Bund-Länder-Kommission für Bildungsplanung und Forschungsförderung (BLK) (BundLaender-Commission for Educational Planning and Research Promotion) (1995). Medienerziehung in der Schule - Orientierungsrahmen (Orientation framework for media education at school). BLK Materialien zur Bildungsplanung und zur Forschungsförderung, Heft 44. Bonn: BLK.

http://www.iid.de/schule/sonstiges/heft 44 .html

Chuuou Kyouiku Shingikai (Central Council for Education) (1996, Jul). 21seiki wo tenbou shita waga kuni no kyouiku no arikata ni tsuite. Chuuou Kyouiku Shingikai dai ichi ji toushin. mokuji (How Japanese Education Ought to be Looking Towards the 21st Century. 1st Report of the Central Council of Education. Index.).

http://www.mext.go.jp/b_menu/shingi/chuuou/toushin/960701.htm

Chuuou Kyouiku Shingikai (Central Council for Education) (1997a, Jun), The model for Japanese education in the perspective of the 21st Century (2nd Report).

http://www.mext.go.jp/english/shougai/970601.htm

Chuuou Kyouiku Shingikai (Central Council for Education) (1997b). 21seiki wo tenbou shita waga kuni no kyouiku no arikata ni tsuite. Chuuou Kyouiku Shingikai dai ni ji toushin (zenbun) (The model for Japanese education in the perspective of the 21st Century (2nd Report)). http://www. monbu.go.jp/singi/00000058/

\footnotetext{
${ }^{55}$ http://pcen100.ed.kanazawa-u.ac.jp/kurokami/joho/ (Kurokami's interpretation of "jouhou")
} 
Hauf-Tulodziecki, A. (1996, Apr). Warum es nicht reicht, nur Computer in die Schulen zu stellen - Erfahrungen mit der Einführung der informationstechnischen Grundbildung (Why it is not enough to just put computers into schools - experiences with the introduction of basic information technology education).

http://tamarillo.hagen.de/FORUM/ITG.Hauf.html

Hauf-Tulodziecki, A. (1999, May). Informatische Bildung und Medienerziehung (Informatics education and media pedagogics). In A. Schwill (Ed.), Fachspezifische und fachübergreifende didaktische Konzepte. 8. GI-Fachtagung Informatik und Schule, INFOS '99, Potsdam, 22.-25. September 1999 (Subject specific and cross subject didactic concepts. 8th GI Coference on Informatics and School, INFOS '99, Postdam, September 22-25, 1999), pp. 121-129. Berlin, Heidelberg, New York etc.: Springer.

http://www. learn-line.nrw.de/angebote/medienbildung/Foyer/GI/gi_

empfehlung.pdf

Hessisches Kultusministerium (Hessian Ministry of Cultural Affairs) (1994). Kursstrukturpläne Gymnasiale Oberstufe, Aufgabenfeld III, 5. INFORMATIK (Curriculum for Gymnasium, grades 11-13, Field III, 5. Informatics).

http://www.bildung.hessen.de/abereich/inform/skii/rplan/ksp.pdf

IMAI Yasuo (1998). Gendai Kyouiku no Genjou to Riron - "Seikatsu to Kagaku" kara "Bi to Media" e. (Present State and Theory of Contemporary Education - from "Life and Science" to "Beauty and Media").

Jouhou shori gakkai shotou chuutou jouhou kyouiku iinkai waakingu guruupu (Information processing society, working group of the committee on information education in primary and secondary schools) (Ed.) (1998). Koutou gakkou futsuuka "Jouhou" shisaku kyoukasho (kashou) (Pilot textbook for the general school subject "information" (provisional name)).

http://www.ics.teikyo-u.ac.jp/Informationstudy/

Jouhouka no shinten ni taiou shita shotou chuutou kyouiku ni okeru jouhou kyouiku no suishin nado ni kansuru chousa kenkyuu kyouryokusha kaigi (Council for research about the promotion of information education in primary and secondary education in response to advancing informatisation) (1997, Oct). Taikeiteki na jouhou kyouiku no jisshi ni mukete (Towards the implementation of systematic information education).

http://www.monbu.go.jp/series/00000026/

KAMEYAMA Hiroshi (1994, Oct). Jouhou kiso no gakushuu shidou (Learning and teaching of information basics). In SASAKI; KONDOU; TANAKA (Ed.), Kaiseihan Gijutsuka kyouikuhou (Methods of teaching technology (revised edition)), pp. 151-170. Gakubunsha.

http://pcb209e.ed.shizuoka.ac.jp/kameyama/Gikyo.htm

Kyouiku Katei Shingikai (The Curriculum Council) (1998a, Jul), Synopsis of the Report "National Curriculum Standards Reform for Kindergarten, Elementary School, Lower and Upper Secondary School and Schools for the Visually Disabled, the Hearing Impaired and the Otherwise Disabled". Primary and Secondary Education.

http://www.mext.go.jp/english/news/1998/07/980712.htm

Kyouiku Katei Shingikai (Curriculum Council) (1998b, Jul). Youchien, shougakkou, chuugakkou, koutou gakkou, mougakkou, rougakkou oyobi yougo gakkou no kyouiku katei no kijun no kaizen ni tsuite (toushin) ("National Curriculum Standards Reform for Kindergarten, Elementary School, Lower and Upper Secondary School and Schools for the Visually Disabled, the Hearing Impaired and the Otherwise Disabled" (Report)).

http://www.monbu.go.jp/singi/katei/00000216/index.html

Lachmann, M.; Beck, H. (1998). Internet als Motor für eine neue Didaktik (Internet as a motor for a new didactics). Journal for school development, 42-48.

Langner, I. (2000, Mar). Internetworking Activities at Japanese and German Schools (1994-1999). In IKUTA Takashi (Ed.), Doitsu oyobi Nihon ni okeru sougouteki gakushuu to atarashii kyouiku media no kanren ni kansuru hikaku kenkyuu. Heisei 
10 nendo - heisei 11 nendo (kiban kenkyuu (B)(2)) kenkyuu seika houkokusho (Comparative research about interdisciplinary learning and new educational media in Germany and Japan. 1998-1999 (research report (B)(2))), pp. 45-60. Niigata University.

http://www.gmd.de/People/Irene. Langner/docs/200003/houkoku200003.ps

Ministerium für Schule und Weiterbildung, Wissenschaft und Forschung des Landes Nordrhein-Westfalen (Ministry for School, Continuous Education, Science and Research of North Rhine-Westphalia) $(1999,1)$. Richtlinien und Lehrpläne für die Sekundarstufe II Gymnasium/Gesamtschule in Nordrhein-Westfalen, Heft 4725: Informatik (Guidelines and curricular for higher secondary education - Gymnasium and comprehensive school in North Rhine-Westphalia, No 4725: Informatics).

http://www.schul-welt.de/verlag/schulwelt/lp_online_download.asp?

sessionid=[Changing_No.] $\&$ file $=4725$.pdf

MizuKoshi Toshiyuki (1990, Aug). Shin Gakushuu Shidou Youryou ni okeru jouhouka e no taiou (Accomodation to informatisation in the new course of study). In YАMАMOTO Masao (Ed.), Jouhouka kyouiku tokuhon. Jouhou katsuyou nouryoku o ikusei suru gakushuu shidou no riron to jissen. (Reading book on information education. Theory and practice of teaching and learning for the cultivation of information literacy.), pp. 50-55. Tokyo: Kyouiku Kaihatsu Kenkyuusho.

Mizukoshi Toshiyuki; AKAhORI Kanji (Ed.) (1995, Nov). Kyouiku media riyou no kaizen (Improvement of educational media use), Tokyo. Kokuritsu Kyouiku Kaikan.

Monbushou (Ministry of Education) (1989, Mar). Gakushuu shidou youryou (Course of Study). http://www.mext.go.jp/a_menu/shotou/youryou/101/index.htm

Monbushou (Ministry of Education) (1994, Dec). Waga kuni no bunkyou shisaku (Japan's Educational Policy). Tokyo: Ookurashou Insatsukyoku.

Monbushou (Ministry of Education) (1997, Jan), Program for Educational Reform (Lifelong Learning Policy).

http://www.mext.go.jp/english/shougai/971001.htm

Monbushou (Ministry of Education) (1998, Oct). Waga kuni no bunkyou shisaku (Japan's Educational Policy). Tokyo: Ookurashou Insatsukyoku.

Monbushou (Ministry of Education) (1999a, Mar). Gakushuu shidou youryou (Course of Study). http://www.mext.go.jp/b_menu/shuppan/sonota/990301.htm

Monbushou (Ministry of Education) (1999b, Mar). Koutou gakkou gakushuu shidou youryou, dai 2 shou: futsuu kyouiku ni kansuru kaku kyouka, dai 10 setsu: jouhou (Course of Study for high schools, chapter 2: subjects for general education, paragraph 10: Information). http://www.mext.go.jp/b_menu/shuppan/sonota/990301d/990301k.htm

Mötsch, B. (1997, Sep). Informationelle Bildung in der Schule unter besonderer Berücksichtigung des Internet. Aspekte und Grundlagen curricularer Konzeptionen (Information education at school with special focus on the Internet. Aspects and basics of curricular conceptions). http://www.ub.uni-konstanz.de/kops/volltexte/1999/168

Muranoi H.; Mishima H.; Inui S.; OHnOgi H. (Ed.) (1999, Jul). Gakkou to chiiki de sodateru media riterashii (Raising media literacy in school and region), Kyoto. Nakanishiya.

OOTANI Takashi (1997, spring). Intaanetto ha gakkou kyouiku ni totte toroi no mokuba ka - tekunorojii no kyouiku riyou to gakkou bunka (Is the Internet a Trojan horse for school education? On educational use of technology and school culture). Studies on Evaluation of Learning No. 29, 42-49.

http://WWW.educa.nagoya-u.ac.jp/otani/trojan.html

Pauer, E. (1996), Rules, Goals, Information - A Key to the Question of Continuity and Change in Japan. Philipps-Universität Marburg, Center for Japanese Studies, Occasional Papers Nr. 20. 
Schelhowe, H. (1998). Anwenden - Verstehen - Gestalten. Informatische Bildung in der Informationsgesellschaft (Applying - Understanding - Creating. Informatics education in the information society). In V. Oechtering (Ed.), Computernetze - Frauenplätze. Frauen in der Informationsgesellschaft (Computer networks - women's places. Women in the information society), pp. 99-113. Opladen: Leske \& Budrich.

http://waste.informatik.hu-berlin.de/Schelhowe/Informat.Bildung.html

Schulz-Zander, R. (1997). Medienkompetenz - Anforderungen für schulisches Lernen (Media competence - requirements for school learning). In Enquete-Kommission des Deutschen Bundestags "Zukunft der Medien in Wirtschaft und Gesellschaft; Deutschlands Weg in die Informationsgesellschaft" (Enquete Commission of the German Parliament "Future of Media in Economy and Society. Germany's Way to the Information Society") (Ed.), Medienkompetenz im Informationszeitalter (Media competence in the information age), pp. 99-110. Bonn: ZV Zeitungs-Verlag Service.

Schulz-Zander, R. (1998a). Current Trends in Information and Communication Technology Education in the German School System. In R. Schulz-Zander (Ed.), Information and Communication Technology Changing Schools and Teacher Education, Beiträge zur Bildungsforschung und Schulentwicklung 7, pp. 11-27. Dortmund: IFS-Verlag.

Schulz-Zander, R. (1998b). Multimedia und Netze in Schulen - eine Chance für eine neue Lernkultur? (Multimedia and networks in schools - a chance for a new learning culture?). In H. Kubicek et al. (Eds.), Lernort Multimedia. Jahrbuch Telekommunikation und Gesellschaft 1998, Bd. 6, pp. 139-147. Heidelberg: v. Decker's Verlag.

Ständige Konferenz der Kultusminister der Länder in der Bundesrepublik Deutschland (Standing Conference of the Ministers of Education and Cultural Affairs of the German Länder) (1995, May). Medienpädagogik in der Schule - Erklärung der KMK vom 12.05.1995 - (Media pedagogics at school - declaration of the KMK from May 12, 1995).

http://www.kmk.org/doc/publ/medpaed.pdf

Ständige Konferenz der Kultusminister der Länder in der Bundesrepublik Deutschland (Standing Conference of the Ministers of Education and Cultural Affairs of the German Länder) (1997, Feb). Neue Medien und Telekommunikation im Bildungswesen - Sachstand und Perspektiven im Schul- und Weiterbildungsbereich - Beschluß der KMK vom 28.02.1997 (New media and telecommunication in the education system - State of affairs and perspectives in school and continuing education - Resolution of the KMK from February 28, 1997).

http://www. kmk.org/schul/neuemed2.pdf

Thüringer Institut für Lehrerfortbildung, Lehrplanentwicklung und Medien (ThILLM) (Thuringian Institute for Teacher Training, Curriculum Development and Media (ThILLM)) (1999, Jan). Empfehlungen für das fächerübergreifende Thema Umgang mit Medien und Informationstechniken (UMI) (Recommendations for the cross subject topic "Dealing with media and information technology (UMI)"). Erfurt.

http://www.thillm.th.schule.de/thillm/lehrplan/empfehl/umi.pdf

Thüringer Kultusministerium (Thuringian Ministry of Cultural Affairs) (1999). Lehrplan für das Gymnasium Informatik (Curriculum for Gymnasium informatics).

http://www.thillm.th.schule.de/thillm/lehrplan/lehrpl_gy/99gyinfo.pdf

Tsukuba Kokusai Kyouiku Kenkyuukai (Tsukuba Studygroup for International Education) (Ed.) (1998, Jan). Bairingaru tekisuto Nihon no kyouiku (A Bilingual Text: EDUCATION IN JAPAN), Tokyo. Gakken.

Tully, C. (1994). Lernen in der Informationsgesellschaft (Learning in the Information Society). Opladen: Westdeutscher Verlag.

Wilkens, U. (2000). Das allmähliche Verschwinden der informationstechnischen Grundbildung (The gradual disappearing of basic information technology education). Aachen: Shaker. 
YAMAGIWA Takashi (1991, Oct). Jouhouka e no taiou to jugyou jissen no kaikaku (Accomodation to informatisation and reform of teaching practice). Tokyo: Daiichi Houki (Kabushiki Gaisha).

Zentralstelle für Computer im Unterricht (Central Agency for Computers at School) (2000). Informatik in der Schule. Schwerpunkte, Hinweise auf Materialien, Informationsquellen (Informatics at school. Main points, reference to material, information sources). http://www.schule.bayern.de/texte/Informatik.pdf

\section{URLs}

http: //wWw.educa.nagoya-u.ac.jp/otani/trojan.html ...................... 28 http://pcb209e.ed.shizuoka.ac.jp/kameyama/Gikyo.htm ..................... 27 http://pcen100.ed.kanazawa-u.ac.jp/kurokami/joho/ .......................26 http://tamarillo.hagen. de/FORUM/ITG. Hauf.html ..........................27 http://waste.informatik.hu-berlin.de/Schelhowe/Informat.Bildung.html......29 http://www.bildung.hessen.de/abereich/inform/skii/rplan/ksp.pdf ...........27 http://www.bildung.hessen.de/abereich/rplan/index $3 . h t m \ldots \ldots \ldots \ldots \ldots \ldots \ldots$ http://www.bildung.hessen.de/abereich/rplan/index $4 . h t m \ldots \ldots \ldots \ldots \ldots \ldots \ldots . \ldots 20$ http://www.cec.or.jp/e-cec/CEC \_100school.html .......................... http://www.gmd.de/People/Irene.Langner/docs/200003/houkoku200003.ps......28

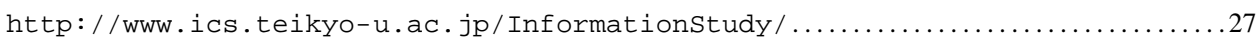

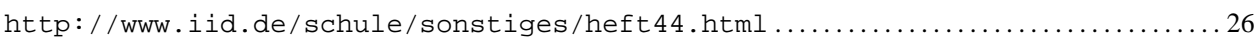

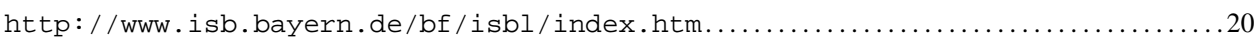
http://www.kmk.org/doc/publ/medpaed.pdf ..............................29 http://www.kmk.org/schul/neuemed2 .pdf ................................. 29 http://www.learn-line.nrw.de/angebote/medienbildung/Foyer/GI/ gi_empfehlung.pdf ................................................ 27

http://www.learn-line.nrw.de/angebote/modell/bevchina/china2.htm .........20 http://www. learn-line.nrw.de/angebote/neuemedien/medio/ikg/ikg.htm........20 http://www.mext.go.jp/a_menu/shotou/youryou/101/index.htm................28 http://www.mext.go.jp/b_menu/shingi/chuuou/toushin/960701.htm.............26 http://www.mext.go.jp/b_menu/shingi/chuuou/toushin/9607010.htm............9 http://www.mext.go.jp/b_menu/shuppan/sonota/990301.htm ..................28 http://www.mext.go.jp/b_menu/shuppan/sonota/990301d/990301k.htm..........28 http://www.mext.go.jp/english/news/1998/07/980712.htm...................27 http://www.mext.go.jp/english/shougai/970601.htm ....................... 26 http://www.mext.go.jp/english/shougai/971001.htm ...................... 28

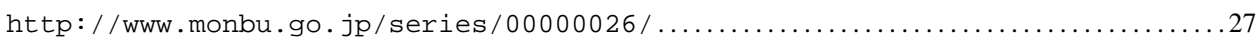
http://www.monbu.go.jp/series/00000056/gif/mokuji2.gif................... 12

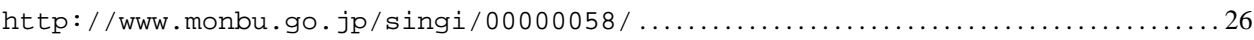
http://www.monbu.go.jp/singi/katei/00000216/index.html .................. 27 